Schaap, Julian \& Aupers, Stef (2017) 'Gods in World of Warcraft exist': Religious reflexivity and the quest for meaning in online computer games. New Media \& Society 19(11): 1744-1760.

http://journals.sagepub.com/doi/abs/10.1177/1461444816642421?journalCode=nmsa

\title{
'Gods in World of Warcraft exist': Religious reflexivity and the quest for meaning in online computer games
}

Julian Schaap \& Stef Aupers

Erasmus University Rotterdam, The Netherlands \& KU Leuven, Belgium

\begin{abstract}
In 'secular' Western societies, religious topics permeate media texts of books, films, series and games and such texts even inform several religious-spiritual movements. Critically expanding on theories about 'fiction-based religion', 'invented religion' or 'hyper-real religion', this article studies if, how and why players of the massively multiplayer online role-playing game (MMORPG) World of Warcraft reflect on religious narratives in the game world and what influence it has on their personal perspective on religion. Based on interviews with 22 international players, three forms of 'religious reflexivity' are distinguished: (1) religious performance, an acting out of offline experiences with religion through online role-playing; (2) religious relativism, a shift from dogmatic atheism to a tolerant attitude towards religion; and (3) religious quests, an increased interest in religion and active 'bricolage' of online religion and official religion to create personal systems of meaning. Online games, it is concluded, can serve as laboratories where youngsters freely experiment with religion outside the established churches.
\end{abstract}

\section{Keywords}

Digital games, massively multiplayer online role-playing game, play, religion, spirituality, World of Warcraft

Contact: j.schaap@eshcc.eur.nl 
Schaap, Julian \& Aupers, Stef (2017) 'Gods in World of Warcraft exist': Religious reflexivity and the quest for meaning in online computer games. New Media \& Society 19(11): 1744-1760. http://journals.sagepub.com/doi/abs/10.1177/1461444816642421? journalCode=nmsa

\section{Introduction}

The Church of the Holy Light is a full-fledged religious organization with an archbishop, a council of bishops, priests and approximately 800,000 members. Followers do not believe in a transcendent god or deity but rather in a spiritual force that permeates everything. The 'Holy Light', as this force is called, enhances human power whereas its advocates embrace the 'path of the three virtues': respect, tenaciousness and deep compassion towards everything that lives. The Church of the Holy Light has a long, turbulent history and can nowadays be found about everywhere in Azeroth (WoWWiki, 2015).

The Church of the Holy Light is not a 'real' religion or spiritual movement but is part of the popular online computer game World of Warcraft (WoW) (Blizzard Entertainment, 2004). Having 12 million players at its peak in 2010, WoW is still played and entertained by about 5.5 million players in 2015 (Statista, 2016). In line with the work of Cusack (2010), Possamai (2005, 2012) and Davidsen (2014), the Church of the Holy Light - among many other religions and spiritualities in WoW can be understood as, respectively, an 'invented religion', a 'hyper-real' or 'fictionbased religion'. Contemporary media products, such as Lord of the Rings, Star Trek, The Matrix and Game of Thrones, are infused with religious and spiritual narratives and consumers often approach them as 'sacred texts' (Partridge, 2004): they appropriate them as religious sources to construct 'subjective myths' (Possamai, 2005) or construct personal 'systems of ultimate significance' (Luckman, 1967). Such texts even inspired new religious movements, like Jediism (based on the Star Wars films), Matrixism (from The Matrix films), The Church of All Worlds (based on Robert Heinlein's 1961 science fiction novel Stranger in a Strange Land) and, perhaps most famous, Scientology (founded by science fiction writer L. Ron Hubbard).

Although fiction-based religions have long been neglected or trivialized in the sociology of religion, they gained more serious academic attention over the last decade (Cusack, 2010; Davidsen, 2014; Partridge, 2004; Possamai, 2005, 2012). Much of this Contact: j.schaap@eshcc.eur.nl 


\section{Published manuscript of:}

Schaap, Julian \& Aupers, Stef (2017) 'Gods in World of Warcraft exist': Religious reflexivity and the quest for meaning in online computer games. New Media \& Society 19(11): 1744-1760.

http://journals.sagepub.com/doi/abs/10.1177/1461444816642421? journalCode=nmsa

ground-breaking work, however, is mainly explorative and sensitizing: it firmly and convincingly establishes that media fiction and religion are combined, without empirically studying how and why consumers engage with media texts in a religious and/or spiritual way. It is of particular value to study computer games in this respect. More than traditional media - literature, film, television - games are 'interactive' media forms that motivate a 'participatory culture' in which (religious) meanings of texts are relentlessly negotiated, reconstructed and co-produced by players (e.g. Jenkins, 1992; Raessens, 2005). In addition, the practice of play in online games informs and is informed by beliefs, values and concerns in everyday life (e.g. Campbell, 2012; Linderoth and Mortensen, 2015; Taylor, 2006).

In this article, we will therefore present a case study on the online computer game WoW. Through qualitative, in-depth interviews with players $(N=22)$, we will analyze the ways in which players appropriate religious narratives in the game world and how this relates to their (non)religious beliefs in everyday life. Using interviews, we move beyond textual analyses of online computer games and focus on the actual experiences that gamers have in interaction with the game, each other, and the way they make sense of these experiences (Baym, 2006). First, we will critically discuss the literature on popular culture and religion and, in doing so, develop a theoretical approach that is firmly grounded in media studies.

\section{Popular culture and religion: a media approach}

In contemporary theories about secularization and a progressive disenchantment of Western society, fiction-based religion is generally not taken very seriously (e.g. Bruce, 2002). Religious meaning-making based on popular culture is regularly framed as 'weak/unrecognized' religion vis-à-vis 'strong/recognized' religions such as Christianity, Hinduism or Islam (Højsgaard and Warburg, 2005). In comparison, fiction-based religions are generally socially and academically perceived as either hoaxes or trivialized as parodies of dogmatic religion (Cusack, 2010). At the heart of Contact: j.schaap@eshcc.eur.nl 
Schaap, Julian \& Aupers, Stef (2017) 'Gods in World of Warcraft exist': Religious reflexivity and the quest for meaning in online computer games. New Media \& Society 19(11): 1744-1760. http://journals.sagepub.com/doi/abs/10.1177/1461444816642421?journalCode=nmsa

this moral dismissal lay a priori ontological and epistemological assumptions that hamper empirical research in this domain.

First, there is a strong, typically modern, tendency to uphold overly rigid distinctions between reality and fantasy; fact and fiction - a binary way of thinking that informs a morally tainted perspective on fiction-based religion as being inferior to 'real' religion. Adam Possamai (2012), who conducted ground-breaking work in the field, introduced the term 'hyper-real religion' and defined it as 'a simulacrum of a religion created out of, or in symbiosis with, commodified popular culture which provides inspiration at a metaphorical level and/or is a source of beliefs for everyday life' (p. 20). Although this is an applicable definition, it still upholds the - essentially moral distinction between 'real' religion and 'fictitious' religion. By grounding his analysis in the work of postmodernist Jean Baudrillard on the proliferation of media simulations and the 'loss of the real' and by connecting it with the neo-marxist theories of Fredric Jameson about the ails of 'late capitalism', moral connotations about fictionbased religion as being 'superficial', 'meaningless' and 'alienating' are incorporated (Aupers, 2012a). We question such a priori assertions and instead propose to empirically study the way people themselves construct media ontologies because it remains to be seen if players indeed draw rigid distinctions between real and unreal. Studies of fan culture, for instance, demonstrate that fictitious media texts are often located between 'fantasy' and 'reality' (Hills, 2002), while consumers of Star Trek or Lord of the Rings actively turn such texts into a reality that feels real - perhaps even more so than the real world (Jenkins, 1992). In a similar vein, Markham (1998) rightly argues about online environments that

[...] when experiences are experienced, they cannot be 'not real'. In a broader sense, terms such as real, hyperreal, not real, or virtual are no longer valid or meaningful as definitions of our experiences because our experiences are not easily separated in these binary oppositions. (p. 120, emphasis in original)

Contact: j.schaap@eshcc.eur.nl 


\section{Published manuscript of:}

Schaap, Julian \& Aupers, Stef (2017) 'Gods in World of Warcraft exist': Religious reflexivity and the quest for meaning in online computer games. New Media \& Society 19(11): 1744-1760.

http://journals.sagepub.com/doi/abs/10.1177/1461444816642421? journalCode=nmsa

This is particularly the case with massively multiplayer online role-playing games (MMORPGs) where 'playing' and 'being' are converging (Bartle, 2004) and players often 'treat the game world as their life world' (Castranova, 2005: 59).

In our empirical study, we therefore suspend assertions about real religion and fictitious religion by focusing on the way players themselves perceive religious game narratives. This approach might also solve another, yet related, problem in the study of fiction-based religion. In the study of religion, the focus has predominantly been on 'belief' as the prime epistemological strategy to engage with religious narratives in fiction. 'Belief' versus 'disbelief' is the binary code underpinning longstanding academic debates about secularization and disenchantment, whereas we may question whether there are other, unacknowledged ways to deal with the supernatural in contemporary society (e.g. Aupers and Houtman, 2010). Particularly, when studying fiction-based religion, the focus on (dis)belief might become problematic since, as During (2002) argues, once 'a particular text is deemed to be fiction, then it is impossible simply to believe in the reality of fictional events, whether they are supernatural or not' (p. 49). Instead of focusing on (dis)belief as a static disposition, we therefore propose to study fiction-based religion as an unstable, open-ended process of meaning-making that can be called religious reflexivity. This sensitizing concept is informed by media studies demonstrating that avid readers of media texts are involved in 'textual poaching': they unravel different layers and deeper meanings (Jenkins, 1992) and are involved in decoding, negotiating and subverting the 'hegemonicdominant encodings' (Hall, 1980[2005]). Online texts are not decoded in quarantine but stand in constant relation with offline experiences and vice versa (Campbell, 2012). In our case study, then, media consumers may or may not align with the religious narrative in the text: whether they use it as a source of inspiration and how and why they do this remains an open empirical question.

In this study, then, we aim to empirically examine this religious reflexivity in empirical detail and its consequences for everyday life. Given this emphasis on Contact: j.schaap@eshcc.eur.nl 


\section{Published manuscript of:}

Schaap, Julian \& Aupers, Stef (2017) 'Gods in World of Warcraft exist': Religious reflexivity and the quest for meaning in online computer games. New Media \& Society 19(11): 1744-1760.

http://journals.sagepub.com/doi/abs/10.1177/1461444816642421? journalCode=nmsa

reflexivity, we deliberately chose to study the case of online computer games. More than most media, digital games are viable for individual reflexivity as consumers actively interact with the game content and other players in a position between 'casual relaxing' and 'committed entertaining' (Kallio et al., 2011). Particularly, role-paying games (RPGs) accommodate greater interaction, as role players predominantly focus on character/avatar development and the creation of coherent storylines with the explicit purpose of interacting with other players (MacCallum-Stewart and Parsler, 2008; Robinson, 2007). While playing, gamers are immersed in 'virtual worlds' (Bartle, 2004), 'synthetic worlds' (Castranova, 2005) or 'social third spaces' (Feltmate, 2010) that provide gamers the possibility to safely experiment with identity, emotions and worldviews - much like a private laboratory (Jansz, 2005; Linderoth and Mortensen, 2015; Turkle, 1995). This perceived safety may be particularly attractive for people belonging to a (spiritual and/or religious) minority (Mehra et al., 2004). The main questions are then as follows: First, if, how and why do online gamers reflect on religious narratives in the game? Second, what influence does this have on their personal assumptions about religion in the offline world?

\section{The case of WoW}

This study is based on 22 in-depth interviews with players of WoW - the popular MMORPG produced by Blizzard Entertainment (2004). WoW was launched in 2004 and had extensions in 2007 (The Burning Crusade), 2008 (Wrath of the Lich King), 2010 (Cataclysm), 2012 (Mists of Pandaria) and 2014 (Warlords of Dreanor). At the time of research, the game hosted 9.6 million international subscribers (Activision Blizzard Inc., 2013; Statista, 2016), making it the best-selling MMORPG to date. Studies on WoW commented on historical narratives in the game (e.g. Bainbridge, 2007; Krzywinska, 2006; Schwartz, 2006), morality (e.g. Luck, 2009), racism and colonialism (e.g. Langer, 2008; Monson, 2012) and, most relevant for this study, the 
Schaap, Julian \& Aupers, Stef (2017) 'Gods in World of Warcraft exist': Religious reflexivity and the quest for meaning in online computer games. New Media \& Society 19(11): 1744-1760. http://journals.sagepub.com/doi/abs/10.1177/1461444816642421?journalCode=nmsa

primacy of religion, mysticism and magic in the game world (e.g. Aupers, 2012b; Aupers and Schaap, 2015; Feltmate, 2010).

Like most MMORPGs, the world of WoW (Azeroth) is primarily based on an idealized medievalist society beyond the modern 'disenchanted world' that is suffused with popular mythology, legends, folklore and that provides countless magical opportunities and skills for players. Such a typical combination of nostalgia and mysticism, Krzywinska (2006, 2008) argues, provides the player with the idea that he or she is not encountering fictitious knowledge but rather 'a "lost" way of seeing the world', and hence fosters 'mythic play'. Such 'recognizable cultural histories, epistemologies, and geographies', Monson (2012: 53) adds, inspire players to suspend 'disbelief and accept the more fantastical elements of such stories'. Within this context of fantasy and re-enchantment, one finds countless religious movements and rituals in WoW. Monotheism, as manifested in the Church of the Holy Light, is one example. In general, however, polytheism, animism and magic are more prominent in the attempt to install a feeling of Otherness and re-enchantment (Aupers, 2007). In WoW, one finds the Sisterhood of Elune (night elves worshipping the 'moon goddess'), but also 'druidism', 'shamanism' and different cults (e.g. the Cult of the Forgotten Shadows) which provide an opportunity to engage with religion and spiritual ideas in the game world.

\section{Data and methods}

Unlike most studies on 'invented religion' or 'hyper-real' religion, we have not selected on WoW players with a strong affinity with religion online. To remain open to all kinds of religious reflexivity, including overly negative or atheist perspectives on religion, we placed an open call for interviews on three international WoW-related online forums (www.mmo-champion.com; www.WoWhead.com/forums; http://www.battlenet.eu.WoW/en/forum) with the permission of the forums' moderators. In this call, we invited gamers willing to share experiences of playing WoW, talk about their avatar(s), their background and the influence the game has on Contact: j.schaap@eshcc.eur.nl 


\section{Published manuscript of:}

Schaap, Julian \& Aupers, Stef (2017) 'Gods in World of Warcraft exist': Religious reflexivity and the quest for meaning in online computer games. New Media \& Society 19(11): 1744-1760.

http://journals.sagepub.com/doi/abs/10.1177/1461444816642421? journalCode=nmsa

everyday life. Initially, we received 31 responses. Most (27) came from 'role-playing gamers' (RP) rather than 'player-versus-player gamers' (PvP, 4), as the latter type typically engages less with in-game content. Our role-playing respondents slightly deviate from the average WoW player as over half of MMORPG gamers prefer the competition and achievement attached to $\mathrm{PvP}$, which is less present in role-play (Billieux et al., 2013; Langer, 2008).

Of the 31 initial responses we received, 22 players (19 RP and $3 \mathrm{PvP}$ ) were willing to be interviewed in-depth using video conferencing software Skype. Although not having interviews in a face-to-face context might be a drawback in carrying out qualitative research (e.g. Roulston, 2010), there are many merits to undertaking digital interviews (cf. Bertrand and Bourdeau, 2010; Hanna, 2012). Fervent gamers are often in their maximum comfort zone behind their personal computer (PC) screens, are accustomed to online sociality and are well-heeled in using video conferencing and chatting software. Furthermore, three of our respondents reported that they were 'shy' and said they would not easily agree to be interviewed in an offline (institutional) setting. Using Skype, we managed to include this small group in the sample.

Due to the international nature of the WoW servers, respondents had varying nationalities (see Table 1). The male-female ratio of the sample was skewed (18 male, 4 female) but in coherence with findings on gender inequality in video game consumption (Billieux et al., 2013; Taylor, 2006). The average age of the interviewees was 21.9 years with the youngest respondents being 17 years and the oldest 34 years. This is slightly younger than the average age (26 years) of MMORPG players (Billieux et al., 2013; Yee, 2006) but still falls within the brackets of the average young-adult age group that most MMORPG players are in. In line with the average adolescent and young-adult age category of these gamers, most respondents reported to be unemployed or prospective students $(40.9 \%)$ or students $(31.8 \%)$. The rest were generally older and reported to work in low-wage jobs $(13.6 \%)$, were self-employed $(9.1 \%)$ or worked in information technology (IT; 4.5\%). In each interview, respondents reported their religious affiliation.

Contact: j.schaap@eshcc.eur.nl 


\section{Published manuscript of:}

Schaap, Julian \& Aupers, Stef (2017) 'Gods in World of Warcraft exist': Religious reflexivity and the quest for meaning in online computer games. New Media \& Society 19(11): 1744-1760.

http://journals.sagepub.com/doi/abs/10.1177/1461444816642421? journalCode=nmsa

Half of the respondents claimed atheism or agnosticism $(50 \%)$, while the other half affiliated with New Age or Eastern spirituality (18.2\%), Christian denominations (13.6\%) or reported to believe in 'something' $(18.2 \%)$.

A semi-structured interview guide was used. Respondents' nationality, gender and age were recorded before the interview and their level of education, socioeconomic background and religious affiliation during the interview or afterwards if it was not mentioned in the conversation. As an opening question, respondents were asked to discuss their favourite or main character which they play(ed) in WoW. After going through the character's backstory, we requested of interviewees to clarify the reasons for choosing this character and backstory. Here, questions were asked on choices on the avatar's character, life path and positions towards magic, spirituality and religion in WoW. Using this as a springboard, the interview from then onwards focused on the respondents' offline lives, inquiring into processes of identification and reflection particularly with regard to religion and spirituality.

All interviews, apart from one interview with a Dutch respondent, were conducted in English. Interviews lasted from 40 minutes (Max, 31 years) to over 2 hours (Olivia, 20 years) and were recorded and transcribed verbatim. Given the exploratory and theorygenerating goal of this study, we used an inductive research strategy based on the principles of 'Grounded Theory' (Charmaz, 2006; Glaser and Strauss, 1967). From this perspective, all individual interviews were systematically compared and were subjected to open, axial and selective coding. The coding process generated three ideal-typical dimensions representing different manifestations of religious reflexivity: (1) religious performance and re-enactments, (2) religious relativism and (3) religious quests.

\section{Religious performance and re-enactments}

At the beginning of the game, players choose a faction (Alliance or Horde), race (i.e. human, dwarf, night elf, gnome etc.) and class (i.e. priest, mage, rogue, shaman etc.) and develop their character in interaction with game stories invented by and with other Contact: j.schaap@eshcc.eur.nl 
Schaap, Julian \& Aupers, Stef (2017) 'Gods in World of Warcraft exist': Religious reflexivity and the quest for meaning in online computer games. New Media \& Society 19(11): 1744-1760.

\section{http://journals.sagepub.com/doi/abs/10.1177/1461444816642421? journalCode=nmsa}

players in the participatory culture that WoW offers (Coleman and Dyer-Witheford, 2007). For several players, religion is a significant element in the meaningful construction of their in-game character, while for a few of them, religious narratives even provide the opportunity to re-enact and deal with personal issues with religion in their offline lives.

An example of religious role-playing is Liam. He explains that his female Draenei Priest in the game was raised by her father as a strong devotee to the Holy Light. Unexpectedly, he clarifies, the character was abandoned by her family and hence 'turned away from the Light and is more focused on Shadow magics', something unusual for characters of the Draenei race. This 'corruption of her purity', as Liam sees it, causes her life story to deviate from that of more traditional Draenei storylines,

Table 1. Respondent background characteristics and spiritual/religious affiliations $(N=22)$.

\begin{tabular}{|l|l|l|l|l|l|}
\hline & Name & Gender & $\begin{array}{l}\text { Age } \\
\text { (years })\end{array}$ & Nationality & Self-proclaimed belief(s) \\
\hline 1 & Berndt & Male & 17 & Denmark & Atheist \\
\hline 2 & Carsten & Male & 34 & Romania & Atheist \\
\hline 3 & Cedric & Male & 26 & Sweden & Atheist \\
\hline 4 & Colin & Male & 17 & Denmark & Atheist/Buddhist \\
\hline 5 & Denise & Female & 24 & United States & Catholic \\
\hline 6 & Gabriel & Male & 21 & United Kingdom & Atheist \\
\hline 7 & Harold & Male & 19 & United Kingdom & Atheist \\
\hline 8 & Janick & Male & 19 & Denmark & Atheist \\
\hline 9 & Jason & Male & 16 & United Kingdom & Reincarnation \\
\hline 10 & Joseph & Male & 23 & Poland & Catholic \\
\hline 11 & Karin & Female & 21 & Netherlands & Atheist \\
\hline 12 & Lance & Male & 23 & United Kingdom & Atheist/Misotheist \\
\hline 13 & Liam & Male & 19 & United States & Atheist \\
\hline
\end{tabular}

Contact: j.schaap@eshcc.eur.nl 
Published manuscript of:

Schaap, Julian \& Aupers, Stef (2017) 'Gods in World of Warcraft exist': Religious reflexivity and the quest for meaning in online computer games. New Media \& Society 19(11): 1744-1760.

http://journals.sagepub.com/doi/abs/10.1177/1461444816642421? journalCode=nmsa

\begin{tabular}{|l|l|l|l|l|l|}
\hline 14 & Marcel & Male & 19 & Poland & 'Somethingist' \\
\hline 15 & Marissa & Female & 23 & United States & Pagan \\
\hline 16 & Mathias & Male & 17 & Greece & Agnostic \\
\hline 17 & Max & Male & 31 & Germany & 'Somethingist' \\
\hline 18 & Olivia & Female & 20 & United Kingdom & Secular Humanist \\
\hline 19 & Oliver & Male & 24 & Latvia & $\begin{array}{l}\text { Undefined } \\
\text { spiritual/Buddhist }\end{array}$ \\
\hline 20 & Peter & Male & 28 & Canada & Christian \\
\hline 21 & Roger & Male & 18 & United Kingdom & Atheist \\
\hline 22 & Tim & Male & 23 & United States & Atheist \\
\hline
\end{tabular}

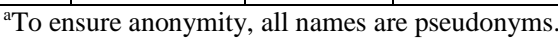

altering the game play substantially to follow a darker and more sinister path. Another, more frivolous example of religious role-playing is Gabriel's extravagant Goblin 'Zizzel'. He is a Shaman who

... currently works as a medic-for-hire but used to work as a model, before he found the work too demanding and turned to the elements. [...] Since he was young he found the ways of Shamanism came easier to him than many others, though he didn't really dabble in it more than he had to.

Here, Gabriel actively creates a pragmatic version of Shamanism that is in coherence with Zizzel's rather unscrupulous and resourceful character.

Performing religion in the virtual world of WoW demands large amounts of time and energy. Respondents note that it sometimes requires substantial investigation to see how a specific religious biography fits a character, a race and the Lore. Janick, for instance, explains how he 'thought about the Holy Light and the culture behind it' when he began to play as a Human Paladin. How can the roles people play be reconciled with the in-game religion? Players browse through books, wikis and forums extensively to decide what to do next when such a dilemma rises. These searches, in

Contact: j.schaap@eshcc.eur.nl 
Schaap, Julian \& Aupers, Stef (2017) 'Gods in World of Warcraft exist': Religious reflexivity and the quest for meaning in online computer games. New Media \& Society 19(11): 1744-1760. http://journals.sagepub.com/doi/abs/10.1177/1461444816642421?journalCode=nmsa

turn, bring them into contact with both fictional WoW religions, but, more importantly, make them reflect on existing religions and more recent forms of New Age spirituality. Wikipedia is often mentioned as a place where existing religions are compared with those offered in WoW, demonstrating how the Internet is actively utilized as a repository for information on religion (cf. Campbell, 2010). Based on such investigations, players regularly draw parallels between the religions in Azeroth and those in the offline world, but they also look for elements in existing religions to use in the performance of their characters. Peter, for instance, finds overlap between the Holy Light and Christianity, as 'you can see it as a single deity'. Colin, on the other hand, considers a comparison between online Tauren culture and Buddhism. He comments, 'they're all like, you know, “we want peace and we can't harm each other" and they believe in being reborn too'. Encountering Tauren culture made Colin search for information on Buddhism's history and philosophy - including watching documentary films where you 'see these monks talking about how you should get through life and how you should live life and how you should just, you know, live in peace and just try to be happy instead of hurting each other'.

Like many other digital games, WoW facilitates the possibility to playfully experiment with deviant, controversial, marginalized or immoral behaviours (Linderoth and Mortensen, 2015). Many respondents perform religious worldviews that are partly or fully oppositional to their personal worldviews. Most respondents are self-reported atheists, yet, often because of that, they enjoy creating and role-playing religious characters like priests and reverends. Playing with the reality of an enchanted world is seen to be vital for this experience. As Lance states, 'WoW is an opportunity for me to play with the consciousness of people who think about gods like people in our world do'. And vice versa, all Christian respondents in the sample reported experimenting with atheism in the game. By creating stories in which belief in god(s) and supernatural influence is denied and by focusing a character's powers on nature's potential or physical strength, a form of in-game atheism is shaped. Joseph, for example, who grew

Contact: j.schaap@eshcc.eur.nl 
Schaap, Julian \& Aupers, Stef (2017) 'Gods in World of Warcraft exist': Religious reflexivity and the quest for meaning in online computer games. New Media \& Society 19(11): 1744-1760. http://journals.sagepub.com/doi/abs/10.1177/1461444816642421?journalCode=nmsa

up in rural Poland and was raised as a strict Catholic, considers such experiments with an atheist identity a 'guilty pleasure'. In line with other research, we find that these gamers develop characters that 'express parts of the self that they have found necessary to suppress or efface in the offline world' (Robinson, 2007: 98) since they are considered 'controversial' and taboo (Linderoth and Mortensen, 2015: 4). When asked whether such activities influence their worldviews, however, respondents often argue that 'it's just a game' to deflect possible emotional impact.

But the latter is not always the case. The most personal form of performing religion in WoW is when players seriously and consciously re-enact their own religious past in the game. Olivia, for instance, comes from a highly religious background but tries with one avatar to uphold her newly regained atheistic worldview in the spiritually infused game environment of WoW. Olivia's character feels that 'it [magic; JS/SA] can be studied without belief' and she uses this study to come to terms with her atheism. Berndt provides another example of an online re-enactment of worldviews. He has three characters that all represent a specific spiritual period in his life. As he explains practically in third person,

The young one, he had conflicting feelings about religion. Part of him just wanted to say 'fuck it all' while other parts of him said 'yeah this is right'. But the middle one, he was kind of sceptical. He didn't really have any belief. He shunned the others; he shunned every belief and just had his own, just to have control. While the third, he had it all figured out. He had his feet planted firmly in his belief.

This third avatar most accurately symbolizes Berndt's current position as an atheist, while the first and second characters are representative of his former years of religious longing.

Denise states that all her avatars re-enact religious struggles she experienced while going through adolescence. Growing up in a small community in the United States, she was raised as a Catholic, but during her adolescence, she had multiple periods in which 
Schaap, Julian \& Aupers, Stef (2017) 'Gods in World of Warcraft exist': Religious reflexivity and the quest for meaning in online computer games. New Media \& Society 19(11): 1744-1760. http://journals.sagepub.com/doi/abs/10.1177/1461444816642421?journalCode=nmsa

she turned away from belief. This strained relationships with her parents, family and community. While having confidently returned to Catholicism since her early 20s, she used her avatars to try out alternative life paths based on her personal struggles. Among those is the playing out of a story where she did not return to her faith (in-game not Catholicism but the Church of the Holy Light) at the cost of losing ties with her family - an opportunity impossible in offline reality. She explains that performing these alternate historical narratives strengthened her in the choices she made in life. This personal biography is carried on through her Human Paladin 'Insiferia', who she still needs to 'redeem for the Church of Light' every so often.

A different re-enactment of personal religious trauma is performed by Lance. Having had a bad experience with religion in his youth, he developed the character Bertrandt, who cherishes an intense hatred for the gods in WoW:

He hates god, because he had a really bad experience with a god. [...] He was told all his life 'hey, you know, do what you need to do, do your duty, protect the forest, worship, be a good person, and your god will look after you. You'll be fine and the stuff that you have lives for will carry on. And if you die, all that stuff is gonna carry on because you're part of something greater. Don't worry, kid'. And then it was like: 'no actually, your god couldn't protect you when the whole world pretty much ended'.

\section{Religious relativism}

A significant effect of constantly being in contact with an enchanted world and with a wide variety of possible religions and spiritualities is that players of WoW relativize their strong ideas about religion in the offline world. Apart from the aforementioned process of comparing worldly religions with those found in $\mathrm{WoW}$, respondents regularly report a more open-minded attitude towards religious diversity in the real world - crediting the game for expanding their empathetic abilities. This increased tolerance is predominantly explained through an alleged confrontation with different traditions and religious worldviews online.

Contact: j.schaap@eshcc.eur.nl 


\section{Published manuscript of:}

Schaap, Julian \& Aupers, Stef (2017) 'Gods in World of Warcraft exist': Religious reflexivity and the quest for meaning in online computer games. New Media \& Society 19(11): 1744-1760.

http://journals.sagepub.com/doi/abs/10.1177/1461444816642421? journalCode=nmsa

An example is Tom. As an atheist, he was originally strictly opposed to theist argumentation, along the lines of the new atheist movement's rationale (Cimino and Smith, 2011). However, while discussing his experiences in role-playing his Paladin, who is a pious devotee to the Holy Light, Tom explains how WoW inspired him to think about religion in a mild way formerly unknown to him:

I'm not religious, but I do think about those big questions, and trying to find if there is an answer that I can find or a reason. I wouldn't go as far to say that WoW holds answers in that or has the promise of them, but looking at their belief systems [Paladins and the Holy Light; JS/SA] and why they see things like that does make me wonder about our own, and why we sometimes think as we do.

Another recurring theme is that atheists find their encounters with religion in a virtual world food-for-thought for their own ontological assumptions. Many respondents mention that it is comforting that supernatural beings, magic and gods are visible and tangible in the game; they have direct measurable effects and, unlike in real life, they need not to be questioned. While this does not change their atheist stance, they admit that this online religion appeals to them exactly because they are not capable to believe in offline life. Their stance may be equated with the classic $X$-Files poster which offers the assessment ' $\mathrm{I}$ want to believe'. Janick is an atheist but, simultaneously, finds the idea of magic and a supernatural power actually existing very interesting. Likewise, Colin embraces a materialistic worldview but nevertheless argues that due to his encounter with beliefs and religions in WoW, 'I'm always open to things'. Lance affirms that he is keen to believe in life after death but is unable to do so since there is no empirical proof. In WoW, however, supernatural assumptions, gods and magic can be fully embraced without the imperative to believe:

For me there is a fundamental difference between the gods in WoW and the gods in real life. The gods in WoW exist and the gods in real life do not. And that sounds like I'm being a petty, sort of atheist douchebag making a point, but it's not exactly like that. [...] In both Contact: j.schaap@eshcc.eur.nl 
Schaap, Julian \& Aupers, Stef (2017) 'Gods in World of Warcraft exist': Religious reflexivity and the quest for meaning in online computer games. New Media \& Society 19(11): 1744-1760. http://journals.sagepub.com/doi/abs/10.1177/1461444816642421?journalCode=nmsa

WoW and in Terry Pratchett's Discworld [fantasy novel series; JS/SA], gods exist. And gods exert power. And if you piss of a god, the god will strike you with lightning.

Finally, Jason expresses his wish to see science being disproved by magic 'because science has begun to dominate our entire society', although he stands behind science for its rational explanation of the world.

Besides relativizing (a)theism through the game, respondents report increased openness to religious diversity in society. Roger, who distilled both Buddhism and Wiccan Paganism from the game, reflects that seeing this religious diversity in WoW made him 'more mature'. On encountering different religious explanations in WoW, he explains that 'even though I wouldn't take it up myself, I do see the logic myself, like not believing in an actual god but instead just living life through logical means', with which he implies the Buddhist values of having respect for each other and nature rather than believing in a god. Similarly, when discussing his sister's choice to become a Wicca devotee, Roger explains that 'I just sort of eye-roll and say "yeah, sure, whatever". But basically, it is really nice, depending on which little aspect of Wiccanism you actually are living by and it is quite a refreshing outlook on life'. This tolerance towards religious diversity is shared by Tom. He finds it

an interesting aspect to WoW, looking at those sort of things, and a realization that in that world, there are multiple right answers to all that [spirituality; JS/SA], and that it is a personal choice for the individual and the race.

\section{Religious quests}

Religious performances, re-enactments and relativism all deviate from the assumption that religious reflexivity in and around popular culture instantly leads to fiction-based or hyper-real religions. Nevertheless, some respondents mention that their experiences in Azeroth motivated a quest for 'ultimate meaning' in which they actively combined different religious assumptions and traditions. These activities are - unlike the forms of Contact: j.schaap@eshcc.eur.nl 
Schaap, Julian \& Aupers, Stef (2017) 'Gods in World of Warcraft exist': Religious reflexivity and the quest for meaning in online computer games. New Media \& Society 19(11): 1744-1760. http://journals.sagepub.com/doi/abs/10.1177/1461444816642421? journalCode=nmsa

reflexivity discussed above - conscious religious quests rather than unintentional consequences of religious role-playing.

Recapitulating on his triple-character religious re-enactment, Berndt discusses how WoW facilitated his spiritual search. Predominantly, by representations of religions in WoW, he went through phases of Buddhism and Shamanism. Berndt's ideas about Buddhism were drawn from the Lore of the 'Pandarians', whereas his Shamanism was based on WoW's use of 'elementals'. Combining aspects of WoW with Northern mythology, he also developed a personal religious outlook called 'Balancism', claiming a guild (group of players) as followers. After this spiritual search - at the time of the interview - Berndt left these ideas and became an atheist. Nevertheless, he proclaims that for him

[i]t's not about finding faith, it's not about finding the truth of everything. It's about finding the truth about yourself and yourselves. [...] It [his religious quest; JS/SA] meant really much to me. [...] In a really short period of time I created my own religion, kinda.

Colin, who at the time of the interview still struggled a lot with his mother's death, is interested in Eastern ideas about reincarnation. His confrontation with Tauren culture led him to self-study Buddhism and Hinduism, merging these beliefs into something that worked for him. As he explains,

I came across the Taurens one day and I became really interested. So I started reading a lot about it. So I just Googled around and found a lot of information and I got really interested in just reading about it. [...] I could see how it looked a lot like Hinduism and Buddhism. So I Googled a lot about that too and watched quite a few movies about it. [...] It had a big impact on my life and it changed the way of looking at things.

Lance draws extensively from both popular culture and philosophical works to create narratives for his characters. Discussing the effects WoW had on his personal 
Schaap, Julian \& Aupers, Stef (2017) 'Gods in World of Warcraft exist': Religious reflexivity and the quest for meaning in online computer games. New Media \& Society 19(11): 1744-1760. http://journals.sagepub.com/doi/abs/10.1177/1461444816642421?journalCode=nmsa

religious development, he explains, 'I have definitely used it [WoW; JS/SA] to explore other faiths. All of my characters apart from Bertrandt are very religious actually'.

Finally, Jason, who is still actively searching for a definite spiritual outlook, uses WoW in his religious quest. Although Jason does not believe in a god, he does believe that 'you do go somewhere' beyond this worldly life after one deceases. In a religiousthought experiment, Jason expresses that 'It is possible that Azeroth is somewhere. It is possible that it could exist. Is it possible that we can discover it?' He continues,

I believe that because modern society has been influenced to believe that if it's on a screen, then it's not real. But what if it is actually out there? What if the races do exist but just remain hidden via the lack of technology to be found?

Ironically, then, the 'wonder' of highly developed technology (i.e. the creation of a full-fledged, immaterial virtual world) opens up the possibility to him that supernatural entities may exist in the 'real' natural world as well.

\section{Conclusion and discussion}

Academic advocates of secularization and critics of religion have often argued that progressive science undermines the validity of religious truth claims made in holy books like the Bhagavad Gita, Quran or Bible. Stories in the Bible, self-proclaimed atheist Richard Dawkins (2006) writes, have been proven to be as 'factually dubious' as the stories of King Arthur, The Da Vinci Code or other forms of popular fiction (p. 123). Ironically, however, this deconstruction does not necessarily indicate the end of religiosity in Northwestern Europe. Quite the contrary, it may have opened up the door for a symbolic reading of the Bible (Campbell, 2008) and a religious engagement with all kinds of media texts in popular culture (e.g. Cusack, 2010; Davidsen, 2014; Possamai, 2005, 2012). Aiming to go beyond mere descriptive case studies of fictionbased religion, we studied if, how and why players of WoW do reflect on religious narratives in the game and, in turn, what influence this has on their assumptions about Contact: j.schaap@eshcc.eur.nl 
Schaap, Julian \& Aupers, Stef (2017) 'Gods in World of Warcraft exist': Religious reflexivity and the quest for meaning in online computer games. New Media \& Society 19(11): 1744-1760. http://journals.sagepub.com/doi/abs/10.1177/1461444816642421?journalCode=nmsa

religion in the offline world. Motivated by a media perspective, we departed from the assumption that game consumers are not so much (non)believers - they should better be seen as reflexive, 'textual poachers' (Jenkins, 1992) who are constantly negotiating the religious codes in the text of the game world of WoW.

Based on 22 qualitative interviews with players of WoW, we were able to make an ideal-typical distinction between three forms of religious reflexivity in WoW. First, players perform religiosity through their character in the game and, in doing so, compare 'real' and 'virtual' religions to add to the meaning of their role-playing. This religious performance becomes most significant for players when personal struggles or even traumatic experiences - with religion are re-enacted within the game. A second type of religious reflexivity refers to a process of religious relativism. Through a constant comparison of online religion and offline religion and an inevitable encounter with different religious views online, players shift from a fundamentalist stance towards a more tolerant perspective on religion. Hardboiled atheist players express more understanding and openness for the religious Other and, in general, the universal longing for ultimate meaning. Finally, some of the respondents comment that playing WoW instigated a veritable spiritual quest - a personal search for answers to existential questions that led to an involvement with different religious sources, traditions and worldviews outside of the game. This third type, then, comes closest to what is described as 'invented religion' (Cusack, 2010), 'fiction-based religion' (Davidsen, 2014) or 'hyper-real religion': by picking, mixing and combining material from The Church of the Holy Light, Tauren culture, Buddhism, Shamanism and so on, players create their personal 'system of ultimate significance' (Luckman, 1967), whereas the media text of WoW 'provides inspiration at a metaphorical level and/or is a source of beliefs for everyday life' (Possamai, 2012: 20).

In general, we hope to have demonstrated that religious reflexivity in online games is a theoretically and societal-relevant phenomenon. Theories about secularization have for long described the decreased social significance of Christian institutions (Bruce,

Contact: j.schaap@eshcc.eur.nl 


\section{Published manuscript of:}

Schaap, Julian \& Aupers, Stef (2017) 'Gods in World of Warcraft exist': Religious reflexivity and the quest for meaning in online computer games. New Media \& Society 19(11): 1744-1760.

http://journals.sagepub.com/doi/abs/10.1177/1461444816642421? journalCode=nmsa

2002) and the 'plausibility problems' of religious claims in a pluralistic society (Berger, 1969). Although such assumptions are accurate when related to institutionalized religion and beliefs, there remains a blind spot in academia for religious transformation and revitalization outside the Christian churches. Nowadays, people are often 'believing without belonging' (Davies, 1994) and freely experiment with different religious traditions, esotericism, occultism and the like to construct their 'private system of ultimate significance' (Luckman, 1967). Such non-institutionalized forms of religion are particularly flowering in the most 'secular' countries in Northwestern Europe (e.g. Heelas et al., 2005; Houtman and Aupers, 2007) and are most prominent among youngsters (Rose, 2005).

How and why young people 'play' with religion outside the churches remains by and large understudied. New media, we suggest, play quite an important role in this. In an extensive ethnographic study, Schofield Clark (2003) found that youngsters use images from film, series and television to frame the supernatural and, in doing so, blur 'the boundaries between religion and fictional legends' (pp. 95-116). Her analysis, however, is mainly restricted to traditional media. More than traditional media, the games we studied are highly interactive and exemplify 'participatory cultures' (Jenkins, 1992; Raessens, 2005) in which consumers are co-producers of the media text and its meaning. More than that, virtual game worlds can be understood as 'laboratories' where adolescents safely try out different 'identities' (Turkle, 1995), freely express deviant emotions (Jansz, 2005) and 'play with the controversial, the forbidden and subversive' through role-playing (Linderoth and Mortensen, 2015: 4). Our study demonstrates how this works in the domain of religion: within the boundaries of the game world, self-proclaimed atheists can safely experiment with the ultimate meanings of (religious) worldviews. And vice versa, religious players can affiliate themselves with the 'guilty pleasure' of a godless existence - with occultism, magic or 'pagan' worldviews that defy their beliefs. These playful in-game activities, the analysis

Contact: j.schaap@eshcc.eur.nl 
Schaap, Julian \& Aupers, Stef (2017) 'Gods in World of Warcraft exist': Religious reflexivity and the quest for meaning in online computer games. New Media \& Society 19(11): 1744-1760. http://journals.sagepub.com/doi/abs/10.1177/1461444816642421?journalCode=nmsa

demonstrates, often have serious consequences for their position vis-à-vis religion in everyday life.

To further assess the exact meanings and implications of these playful religious activities - particularly in the context of secularization theory - we need to move beyond descriptive case studies focusing on small movements such as Matrixism, Jediism, Discordianism and other media cults (e.g. Cusack, 2010; Possamai, 2005). A more general and systematic approach is called for. We need larger qualitative studies or focus groups to further assess the appropriations of religious content and on a more explanatory note - how these are related to the different (non)religious worldviews of players, that is, those of Muslims, Christians, New Agers and atheists. We may also apply survey-based, quantitative research to further study the relationship between atheism and the affinity with religious content, religious roleplaying and immersion in the game world. Do online games provide the opportunity for atheists to experience genuine enchantment without believing, to consume spirituality without converting to a particular religious tradition or doctrine and, ultimately, to find 'ultimate meaning' in a secular and disenchanted world? By empirically studying these questions, we gain a more profound understanding of the way youngsters deal with religion in online games and the broader implications for theories about secularization and religious change in contemporary society.

Contact: j.schaap@eshcc.eur.nl 


\section{Published manuscript of:}

Schaap, Julian \& Aupers, Stef (2017) 'Gods in World of Warcraft exist': Religious reflexivity and the quest for meaning in online computer games. New Media \& Society 19(11): 1744-1760.

http://journals.sagepub.com/doi/abs/10.1177/1461444816642421? journalCode=nmsa

\section{References}

Activision Blizzard, Inc. (2013) Activision announces better-than-expected fourth quarter and calendar year 2012 results. Available at: http://tinyurl.com/bsymfyh

Aupers S (2007) 'Better than the real world': on the reality and meaning of online computer games. Fabula 48(3/4): 250-269.

Aupers S (2012a) 'An infinity of experiences': hyper-real paganism and real enchantment in World of Warcraft. In: Possamai A (ed.) Handbook of Hyper-Real Religions. Leiden; Boston, MA: Brill, pp. 225-246.

Aupers S (2012b) Spiritual play: encountering the sacred in World of Warcraft. In: Frissen V, Lammes S, De Lange M, et al. (eds) Playful Identities: The Ludification of Digital Media Cultures. Amsterdam: Amsterdam University Press, pp. 75-92.

Aupers S and Houtman D (eds) (2010) Religions of Modernity: Relocating the Sacred to the Self and the Digital. Leiden: Brill.

Aupers S and Schaap J (2015) Beyond belief: playing with pagan spirituality in World of Warcraft. Online: Heidelberg Journal of Religions on the Internet 7: 190-206.

Bainbridge WS (2007) The scientific research potential of virtual worlds. Science 317: 472-476.

Bartle R (2004) Designing Virtual Worlds. Berkeley, CA: New Riders Publishers.

Baym NK (2006) Finding the quality in qualitative internet research. In: Silver D and Massanari A (eds) Critical Cyberculture Studies. New York: New York University Press, pp. 79-87.

Berger P (1969) The Sacred Canopy: Elements of a Sociological Theory of Religion. New York: Anchor Books.

Bertrand C and Bourdeau L (2010) Research interviews by Skype: a new data collection method. In: Esteves J (ed.) Proceedings of the 9th European Conference on Research Methodology for Business and Management Studies. Madrid: IE Business School, pp. 70-79.

Billieux J, Van der Linden M, Achab S, et al. (2013) Why do you play World of Warcraft? An in-depth exploration of self-reported motivations to play online and in-game behaviours in the virtual world of Azeroth. Computers in Human Behavior 29: 103-109.

Blizzard Entertainment (2004) World of Warcraft, Video Game, Microsoft Windows and OS X. Irvine, CA: Blizzard Entertainment.

Bruce S (2002) God Is Dead: Secularization in the West. Oxford: Blackwell.

Contact: j.schaap@eshcc.eur.nl 


\section{Published manuscript of:}

Schaap, Julian \& Aupers, Stef (2017) 'Gods in World of Warcraft exist': Religious reflexivity and the quest for meaning in online computer games. New Media \& Society 19(11): 1744-1760.

http://journals.sagepub.com/doi/abs/10.1177/1461444816642421? journalCode=nmsa

Campbell C (2008) The Easternization of the West: A Thematic Account of Cultural Change in the Modern Era. Boulder, CO; London: Paradigm Publishers.

Campbell HA (2010) When Religion Meets New Media. Oxon and New York: Routledge.

Campbell HA (2012) Religion and the Internet: a microcosm for studying Internet trends and implications. New Media \& Society 15(5): 680-694.

Castranova E (2005) Synthetic Worlds: The Business and Culture of Online Games. Chicago, IL; London: The University of Chicago Press.

Charmaz K (2006) Constructing Grounded Theory: A Practical Guide through Qualitative Analysis. London; Thousand Oaks, CA; New Delhi, India: SAGE.

Cimino R and Smith C (2011) The new atheism and the formation of the imagined secularist community. Journal of Media and Religion 10(1): 24-38.

Coleman S and Dyer-Witheford N (2007) Playing on the digital commons: collectivities, capital and contestations in videogame culture. Media, Culture \& Society 29(6): 934-953.

Cusack C (2010) Invented Religions: Imagination, Fiction and Faith. Farnham; Burlington, ON, Canada: Ashgate.

Davidsen M (2014) The spiritual tolkien milieu: a study of fiction-based religion. Unpublished Doctoral Thesis, Universiteit Leiden, Leiden.

Davies G (1994) Religion in Britain since 1945: Believing without Belonging. Oxford; Cambridge, MA: Blackwell.

Dawkins R (2006) The God Delusion. London: Black Swan.

During S (2002) Modern Enchantments: The Cultural Power of Secular Magic. London: Harvard University Press.

Feltmate D (2010) 'You wince in agony as the hot metal brands you': religious behavior in an online role-playing game. Journal of Contemporary Religion 25(3): 363-377.

Glaser BG and Strauss AL (1967) The Discovery of Grounded Theory: Strategies for Qualitative Research. Chicago, IL: Aldine.

Hall S (1980 [2005]) Encoding and decoding. In: Hall S, Hobson D, Lowe A, et al. (eds) Culture, Media, Language. London; New York: Routledge, pp. 117-127.

Hanna P (2012) Using internet technologies (such as Skype) as a research medium: a research note. Qualitative Research 12(2): 239-242.

Contact: j.schaap@eshcc.eur.nl 


\section{Published manuscript of:}

Schaap, Julian \& Aupers, Stef (2017) 'Gods in World of Warcraft exist': Religious reflexivity and the quest for meaning in online computer games. New Media \& Society 19(11): 1744-1760.

http://journals.sagepub.com/doi/abs/10.1177/1461444816642421? journalCode=nmsa

Heelas P, Woodhead L, Seel B, et al. (2005) The Spiritual Revolution: Why Religion Is Giving Way to Spirituality. Oxford: Blackwell.

Hills M (2002) Fan Cultures. London: Routledge.

Højsgaard MT and Warburg M (eds) (2005) Religion in Cyberspace. London; New York: Routledge.

Houtman D and Aupers S (2007) The spiritual turn and the decline of tradition: the spread of post-Christian spirituality in fourteen Western countries (1981-2000). Journal for the Scientific Study of Religion 46(3): 305-320.

Jansz J (2005) The emotional appeal of violent video games for adolescent males. Communication Theory 15(3): 219-241.

Jenkins H (1992) Textual Poachers: Television Fans and Participatory Culture. New York: Routledge.

Kallio KP, Mayra F and Kaipainen K (2011) At least nine ways to play: approaching gamer mentalities. Games and Culture 6(4): 327-353.

Krzywinska T (2006) Blood scythes, festivals, quests and backstories: world creation and rhetorics of myth in World of Warcraft. Games and Culture 1(4): 383-396.

Krzywinska T (2008) World creation and lore: World of Warcraft as rich text. In: Corneliussen HG and Rettberg JW (eds) Digital Culture, Play and Identity: A World of Warcraft Reader. Cambridge, MA; London: The MIT Press, pp. 123-142.

Langer J (2008) The familiar and the foreign: playing (post)colonialism in World of Warcraft. In: Corneliussen HG and Rettberg JW (eds) Digital Culture, Play and Identity: A World of Warcraft Reader. Cambridge, MA; London: The MIT Press, pp. 87-108.

Linderoth J and Mortensen TE (2015) Dark play: the aesthetics of controversial playfulness. In: Mortensen TE, Linderoth $\mathrm{J}$ and Brown AML (eds) The Dark Side of Game Play: Controversial Issues in Playful Environments. New York; London: Routledge, pp. 3-14.

Luck M (2009) Crashing a virtual funeral: morality in MMORPG's. Journal of Information, Communication and Ethics in Society 7(4): 280-285.

Luckman T (1967) The Invisible Religion: The Problem of Religion in Modern Society. New York; London: MacMillan Publishers.

MacCallum-Stewart E and Parsler J (2008) Role-play vs. gameplay: the difficulties of playing a role in World of Warcraft. In: Corneliussen HG and Rettberg JW (eds) Digital Culture, Play

Contact: j.schaap@eshcc.eur.nl 
Published manuscript of:

Schaap, Julian \& Aupers, Stef (2017) 'Gods in World of Warcraft exist': Religious reflexivity and the quest for meaning in online computer games. New Media \& Society 19(11): 1744-1760.

http://journals.sagepub.com/doi/abs/10.1177/1461444816642421? journalCode=nmsa

and Identity: A World of Warcraft Reader. Cambridge, MA; London: The MIT Press, pp. 225-246.

Markham AN (1998) Life Online: Researching Real Experience in Virtual Space. Lanham, MD: Altamira Press.

Mehra B, Merkel C and Peterson Bishop A (2004) The internet for empowerment of minority and marginalized users. New Media \& Society 6(6): 781-802.

Monson MJ (2012) Race-based fantasy realm: essentialism in the World of Warcraft. Games and Culture 7(1): 48-71.

Partridge C (2004) The Re-Enchantment of the West: Volume 1 - Alternative Spiritualities, Sacralization, Popular Culture, and Occulture. London; New York: T \& T Clark International.

Possamai A (2005) Religion and Popular Culture: A Hyper-Real Testament. Brussels: Peter Lang Publishing Group.

Possamai A (ed.) (2012) Handbook of Hyper-Real Religions. Leiden; Boston, MA: Brill.

Raessens J (2005) Computer games as participatory media culture. In: Raessens J and Goldstein J (eds) Handbook of Computer Games. Cambridge, MA; London: The MIT Press, pp. 373-389.

Robinson L (2007) The cyberself: the self-ing project goes online, symbolic interaction in the digital age. New Media \& Society 9(1): 93-110.

Rose S (2005) Transforming the World: Bringing the New Age into Focus. Oxford; Berlin: Peter Lang.

Roulston K (2010) Reflective Interviewing: A Guide to Theory and Practice. Los Angeles, CA; London; New Delhi, India; Singapore: SAGE.

Schofield Clark L (2003) From Angels to Aliens: Teenagers, the Media, and the Supernatural. Oxford; New York: Oxford University Press.

Schwartz L (2006) Fantasy, realism, and the other in recent video games. Space and Culture 9(3): 313-325.

Statista (2016) Number of World of Warcraft subscribers from 1st quarter 2005 to 3rd quarter 2015 (in millions). Available at: http://tinyurl.com/lhwysna

Taylor TL (2006) Play between Worlds: Exploring Online Game Culture. Cambridge, MA: The MIT Press.

Contact: j.schaap@eshcc.eur.nl 


\section{Published manuscript of:}

Schaap, Julian \& Aupers, Stef (2017) 'Gods in World of Warcraft exist': Religious reflexivity and the quest for meaning in online computer games. New Media \& Society 19(11): 1744-1760.

http://journals.sagepub.com/doi/abs/10.1177/1461444816642421? journalCode=nmsa

Turkle S (1995) Life on the Screen: Identity in the Age of the Internet. New York: Simon \& Schuster.

WoWWiki (2015) Church of holy light. Available at: http://tinyurl.com/htuz2h4

Yee N (2006) Motivations for play in online games. Cyber Psychology and Behavior 9(6): 772-775.

Contact: j.schaap@eshcc.eur.nl 